\title{
Idiorrhythmic dose-rate variability in dietary zinc intake generates a different response pattern of zinc metabolism than conventional dose-response feeding* $\dagger$
}

\author{
BY BERISLAV MOMČLOVIĆ ${ }^{1}$, PHILIP G. REEVES ${ }^{2}$ AND MICHAEL J. BLAKE ${ }^{3}$ \\ ${ }^{1}$ Institute for Medical Research and Occupational Health, POB 291, Zagreb, Croatia \\ ${ }^{2}$ United States Department of Agriculture, Agricultural Research Service $\ddagger$, Grand Forks Human Nutrition \\ Research Center, Grand Forks, ND 58202-9034, USA \\ ${ }^{3}$ Department of Pharmacology, University of North Dakota, Grand Forks, ND 58202-9034, USA
}

(Received 17 April 1996-Revised 20 November 1996-Accepted 13 January 1997)

\begin{abstract}
We compared the effects of idiorrhythmic dose-rate feeding and conventional dose-response on the induction of intestinal metallothionein (iMT), expression of aortal heat-shock protein mRNA (HSP70mRNA) induced by restraint stress, and accumulation of $\mathrm{Zn}$ in the femur and incisor of young growing male rats. An idiorrhythmic approach requires that the average dietary $Z n$ concentration (modulo, $M$ ) over the whole experiment (epoch, E) is kept constant across different groups. This is done by adjusting the $\mathrm{Zn}$ concentration of the supplemented diet supplied to compensate for the reduction in the number of days on which $\mathrm{Zn}$-supplemented diet is fed, the latter being spread evenly over the experiment. Idiorrhythms involve offering the diet with $\boldsymbol{n}$ times the overall Zn concentration (M) only every $n$th day with Zn-deficient diet offered on other days. Idiorrythmic $\mathrm{Zn}$ dose-rate feeding changed $\mathrm{Zn}$ accumulation in the femur and incisor in a complex bi-modal fashion, indicating that metabolic efficiency of dietary $\mathrm{Zn}$ is not constant but depends on $\mathrm{Zn}$ dose-rate. In contrast to feeding $\mathrm{Zn}$ in the conventional dose-response scheme, iMT and HSP70mRNA were not affected by idiorrhythmic dose-rate feeding. Idiorrhythmic cycling in dietary $\mathrm{Zn}$ load posed no risk of a biochemical overload nor caused the animals to be stressed. Idiorrhythmic dose-rate feeding brings the dimension of time to the conventional dose-response model.
\end{abstract}

Zinc: Dose-rate idiorrhythm: Intestinal metallothionein: Calcified tissue

Our knowledge of essential nutrient requirements and metabolism is based primarily on experiments where animals are fed on a constant diet, although a constant diet is rarely, if ever, consumed in real life. The broader health and metabolic consequences of natural temporal variability in food intake (Klevay, 1984) and especially that of dose-rate (Momčilović, 1988), are largely unknown. This is surprising, as nutrition may be viewed as a life-long series of time-discrete events.

The habitual consumption of trace elements like $\mathrm{Zn}$ varies widely among individuals, and daily ingestion of $\mathrm{Zn}$ supplements only adds to this natural variability (Smith, 1994). Mertz (1993) reported that the variability in dietary $\mathrm{Zn}$ consumption results in different

* Presented in part at the Experimental Biology '95, April 1995, Atlanta, GA, USA (Momčilović et al. 1995).

$\dagger$ Mention of a trademark or proprietary product does not constitute a guarantee or warranty of the product by the United States Department of Agriculture and does not imply its approval to the exclusion of other products that may also be suitable.

$\ddagger$ U.S. Department of Agriculture, Agricultural Research Service, Northern Plains Area is an equal opportunity/ affirmative action employer and all agency services are available without discrimination. 
metabolic pool sizes and, therefore, as a result of homeostasis, the quantity of $\mathrm{Zn}$ necessary to maintain the existing pool of body $\mathrm{Zn}$ will vary. It was recently shown by Viteri et al. (1995) that variability in nutrient intake, like partitioning between different days, may have important metabolic consequences. They found that true absorption and retention of supplemental Fe was more efficient when administered to normal and Fe-deficient rats every $3 \mathrm{~d}$ rather than daily. Similarly, Gleerup et al. (1995) compared the effect of two different distributions of daily $\mathrm{Ca}$ intake on $\mathrm{Fe}$ absorption from the whole diet and concluded that a reasonable separation of $\mathrm{Ca}$ and $\mathrm{Fe}$ intakes between meals on the same day would improve Fe nutrition.

The logic of cycles and other temporal effects is not the same as the logic of linear and monotonic trends (Kelly \& McGrath, 1988). Recently, an idiorrhythmic feeding regimen was proposed to study the impact of dose-rate in trace element nutrition (Momčilović, 1995). In contrast with the conventional dose-response feeding, the idiorrhythmic doserate feeding mimics natural conditions in a controllable way, i.e., if and when the nutrient is available. This model is based on offering a constant total dose (dose-time equivalent modulo) to animals by inversely correlating the amount and frequency of individual doses (idiorrhythm) over a selected period of time (epoch, E). Viewing the dose as a dose-time equivalent over the time span of an entire experimental $E$ allows one to divide the dose into a series of equal products of different doses with different frequencies. Then they are administered in a regularly recurring pattern to allow the same total dose as if the animals were conventionally fed with $\mathrm{Zn}$ every day, albeit at a different rate. Therefore, idiorrhythmic feeding is a rigorously defined model for dose-rate studies and is in clear distinction to other, predominantly descriptive, concepts of meal and nutrient partitioning.

Recently, it was found that the $\mathrm{Zn}$ dose-rate idiorrhythm induces changes in metabolic efficiency, which in turn generates a complex bi-modal growth response pattern where an intake of dietary $\mathrm{Zn}$ exceeding requirements has a limited capacity to compensate for a previously deficient $\mathrm{Zn}$ intake. This capacity is dependent on both the dose-time equivalent modulo and the dose-rate idiorrhythm (Momčilović, 1995).

The aim of the present experiment was to observe the effects of the idiorrhythmic $\mathrm{Zn}$ dose-rate feeding on $\mathrm{Zn}$ accumulation in the femur and incisor and then compare the results with those of the conventional dose-response model. The femur has already been shown to be the tissue of choice for the assessment of dietary $\mathrm{Zn}$ bioavailability. The incisor should be a useful addition in this respect because of its different growth characteristics (Momčilović et al. 1975a,b). We also wanted to know if the temporal idiorrhythmic increase of $\mathrm{Zn}$ load on dosing days is large enough to invoke a biochemical defence response by inducing intestinal metallothionein (iMT), which is thought to function in $\mathrm{Zn}$ absorption, homeostasis, and protection from metal toxicity (Dunn et al. 1987). Idiorrhythmic dose-rate cycling of dietary $\mathrm{Zn}$ load generates repetitive saltatory response of growth-spurts, -cessation, and -catch-up respectively (Momčilović, 1995), and we are concerned that such a strong environmental stress may induce the expression of stress proteins such as aortal heat-shock, HSP70 (Welch, 1992). We think that understanding the biological mode of operation of idiorrhythmic $\mathrm{Zn}$ dose-rate feeding may prove helpful in the study of the effects of nutrient partitioning across meals, in the nutri-pharmaceutical properties of foods, and in supplementation programmes (Momčilović, 1995).

\section{MATERIALS AND METHODS}

\section{Idiorrhythmic dose-rate experimental feeding design}

Idiorrhythm (I) describes a distinctly proportional and regularly recurrent pattern. An idiorrhythmic approach requires that average dietary $\mathrm{Zn}$ concentration (modulo, $\mathrm{M}$ ) over 
the whole experiment (epoch, E) is kept constant across different groups. This is done by adjusting the $\mathrm{Zn}$ concentration of the supplemented diet supplied to compensate for the reduction in the number of days on which $\mathrm{Zn}$-supplemented diet is fed, the latter being spread evenly over the experiment. Idiorrhythms involve offering the diet with $n$ times the overall $\mathrm{Zn}$ concentration (M) only every $n$th day with $\mathrm{Zn}$-deficient diet offered on other days. Thus for a protocol involving feeding the $\mathrm{Zn}$-supplemented diet every third day, the diet would contain three times the average $\mathrm{Zn}$ concentration and the idiorrhythm would be designated 3M3 (Fig. 1) (Momčilovic,, 1995). The conventional dose-response model, where the nutrient is fed on a continuous daily basis at a constant dose, may be regarded as a special case of an idiorrhythm where the time base is only $1 \mathrm{~d}$.

In a more formal sense, the relationship between the dose-rate idiorrhythm, the selected dose-time equivalent modulo level $\left(\mathrm{Mx} ; \mathrm{x}=\mathrm{mg} \mathrm{Zn} / \mathrm{kg}\right.$ per $\mathrm{d}_{1}$ ), and the sequential number of the day on which the peak dose is administered, i.e., dosing day $\left(\mathrm{d}_{n t h}\right)$, is expressed as: $\mathrm{I}=\left[\mathrm{d}_{n t h}(\mathrm{Mx})\right] / \mathrm{d}_{n t h}$. All of the idiorrhythms that share the same $\mathrm{Zn}$ dosing day $\left(\mathrm{d}_{n t h}\right)$ are considered analogous regardless of their $\mathrm{Zn}$ dose-time equivalent modulo level (Mx). To facilitate the comparison of such analogous idiorrhythms, $\mathrm{Mx}$ is added as a subscript $\left(\mathrm{I}_{\mathrm{Mx}}\right)$.

\section{Experimental diets}

The composition of the basal $\mathrm{Zn}$-deficient diet is shown in Table 1 (Momčilović et al. 1976). It was an egg-white-based diet with supplemental biotin. $\mathrm{ZnCO}_{3}$ and all the other mineral supplements were reagent grade (J. T. Baker, Phillipsburg, NY, USA, and Pflatz and Bauer, Watersbury, CT, USA). The basal Zn-deficient diet closely resembled the AIN93G diet for growing rats (Reeves et al. 1993) except that the mineral mix was reformulated to meet the requirements for $P$ when egg-white is used as the source of protein (Reeves, 1996). The diet contained less than $0.6 \mathrm{mg} \mathrm{Zn} / \mathrm{kg}$ as assessed by inductively coupled Ar plasma atomic emission spectrometry (ICAP-AES) (Nielsen $e t$ al. 1988). Standard reference materials (National Institute of Standards and Technology, Gaithersburg, MD, USA; no. 1572 citrus leaves and no. 1577a bovine liver) were used as quality control materials in the analysis.

Table 1. Basal zinc-deficient diet $(\mathrm{g} / \mathrm{kg})^{*}$

$\begin{array}{lc}\text { Maize starch } & 427.495 \\ \text { Egg white ( } 800 \mathrm{~g} \text { protein } / \mathrm{kg} \text { ) } & 200.00 \\ \text { Dextrinized starch (900 g tetrasaccharides } / \mathrm{kg}) & 100.00 \\ \text { Glucose } & 100.00 \\ \text { Soyabean oil } & 75.00 \\ \text { Fibre (Solka Floc) } & 50.00 \\ \text { Mineral mix (excluding Zn) } \dagger & 35.00 \\ \text { Vitamin mix (AIN-93 modified) } \ddagger & 10.00 \\ \text { Choline bitartrate } & 2.50 \\ \text { Tert-butylhydroquinone } & 0.005\end{array}$

\footnotetext{
* Contained $<0.6 \mathrm{mg} \mathrm{Zn} / \mathrm{kg}$ diet as assessed by inductively coupled Ar plasma atomic emission spectrometry (Nielsen et al. 1988).

† Comprised $(\mathrm{g} / \mathrm{kg}): \mathrm{CaCO}_{3}$ anhydrous 203.76, $\mathrm{CaHPO}_{4} 332 \cdot 27, \mathrm{KH}_{2} \mathrm{PO}_{4}$ 126.79, $\mathrm{MgO} 23 \cdot 68, \mathrm{Na}_{2} \mathrm{SiO}_{3} .9 \mathrm{H}_{2} \mathrm{O} 7 \cdot 25$, $\mathrm{FeSO}_{4} .7 \mathrm{H}_{2} \mathrm{O} 4.98, \mathrm{MnCO}_{3} 0.63, \mathrm{CuCO}_{3} . \mathrm{Cu}(\mathrm{OH})_{2} 0.30, \mathrm{KCr}\left(\mathrm{SO}_{4}\right)_{2} .12 \mathrm{H}_{2} \mathrm{O} 0.275, \mathrm{H}_{3} \mathrm{BO}_{3} 0.0185, \mathrm{NaF}$ powder $0.0635, \mathrm{NiCO}_{3}(45 \% \mathrm{Ni}) 0.0635, \mathrm{SnO} 0.0162, \mathrm{NH}_{4} \mathrm{VO}_{3} 0.0132,\left(\mathrm{NH}_{4}\right)_{6} \mathrm{Mo}_{7} \mathrm{O}_{24} .4 \mathrm{H}_{2} \mathrm{O} 0.0106, \mathrm{Na}_{2} \mathrm{SeO}_{4}$ anhydrous $0.01025, \mathrm{KIO}_{3} 0.010$, glucose to $1000 \mathrm{~g}$.

$\ddagger$ Comprised $(\mathrm{g} / \mathrm{kg})$ : nicotinic acid 3.00 , Ca pantothenate 1.00 , pyridoxine $\mathrm{HCl} 0.70$, thiamin $\mathrm{HCl} 0.60$, riboflavin $0 \cdot 60$, pteroylglutamic acid $0 \cdot 20$, D-biotin 0.02 , cyanocobalamin $(1 \mathrm{~g} / \mathrm{kg}$ in mannitol $) 2.50$, dl- $\alpha$-tocopheryl acetate 15.00 , retinyl palmitate 0.80 , cholecalciferol 0.25 , phylloquinone $75.0 \mathrm{mg}$, glucose to $1000 \mathrm{~g}$.
} 


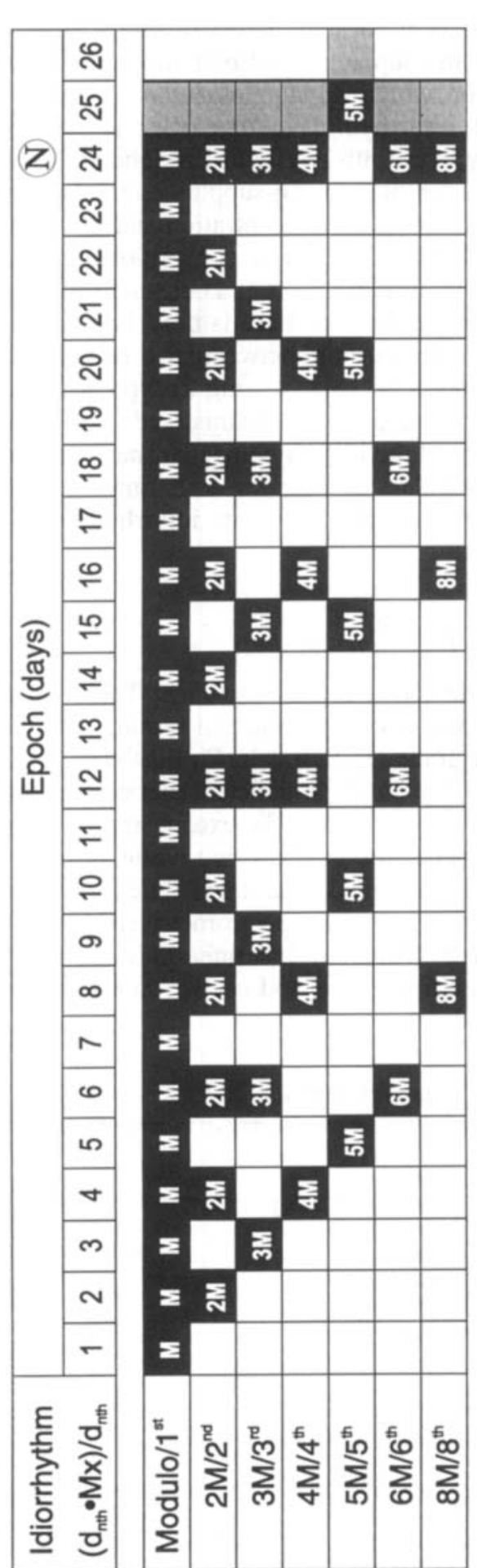

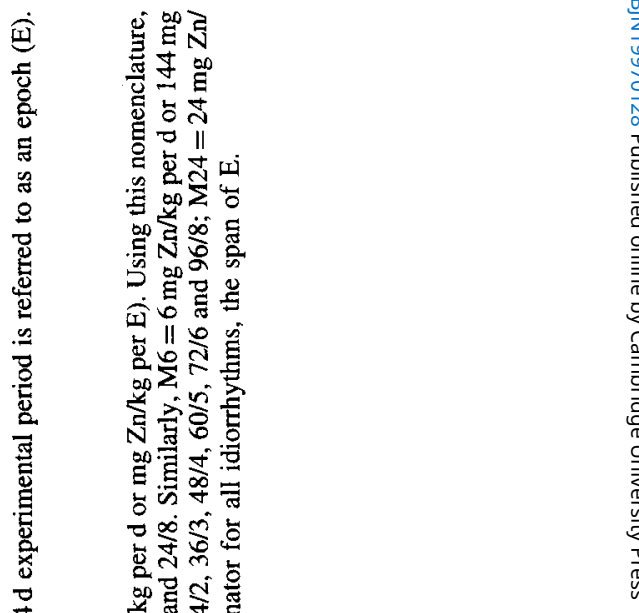

岸吉

$N \infty$

典要

䟲 II

苟过的

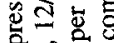

व

范

की

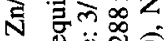

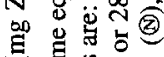

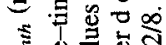

อ

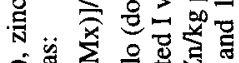

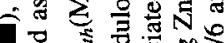

己它告导

焉

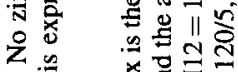

$\times$ 글

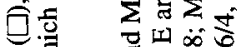

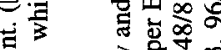

造 要骂高

एक

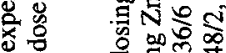

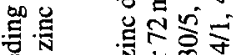

屯

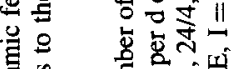

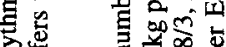

臣娄

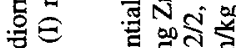

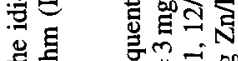

Е

\&

$\therefore \ddot{n}$ 斗的

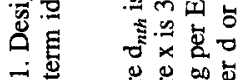

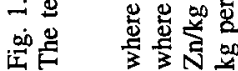


Four representative dose-time equivalent $\mathrm{Zn}$ modulos were chosen over a $24 \mathrm{~d}$ idiorrhythmic $\mathrm{E}$. The four modulos were, $\mathrm{Zn}$-deficient (M3; $3 \mathrm{mg} \mathrm{Zn/kg} \mathrm{per} \mathrm{d}_{1}$ ), low $\mathrm{Zn}$ (M6; $6 \mathrm{mg} \mathrm{Zn/kg} \mathrm{per} \mathrm{d}_{1}$ ), adequate $\mathrm{Zn}$ (M12; $12 \mathrm{mg} \mathrm{Zn/kg} \mathrm{per} \mathrm{d}_{1}$ ), and ample $\mathrm{Zn}$ (M24; $24 \mathrm{mg} \mathrm{Zn} / \mathrm{kg}$ per $\mathrm{d}_{1}$ ). Each modulo had seven analogous dose-rate idiorrhythms arranged in an increasing order: (a) $I=M x / 1 ; 3,6,12$, or $24 \mathrm{mg} \mathrm{Zn} / \mathrm{kg}$ per $\mathrm{d}_{1}$ fed daily, (b) $\mathrm{I}=2 \mathrm{Mx} / 2$; $6,12,24$, or $48 \mathrm{mg} \mathrm{Zn/kd}$ per $\mathrm{d}_{2}$ fed every other day and separated by a day of feeding a Zn-deficient diet, (c) $I=3 \mathrm{Mx} / 3 ; 9,18,36$, or $72 \mathrm{mg} \mathrm{Zn} / \mathrm{kg}$ per $\mathrm{d}_{3}$ fed every third day and separated by $2 \mathrm{~d}$ of feeding a Zn-deficient diet, (d) $\mathrm{I}=4 \mathrm{Mx} / 4 ; 12,24,48$, or $96 \mathrm{mg} \mathrm{Zn/kg}$ per $\mathrm{d}_{4}$ fed every fourth day and separated by $3 \mathrm{~d}$ of feeding a Zn-deficient diet, (e) $\mathrm{I}=$ $5 \mathrm{Mx} / 5 ; 15,30,60$, or $120 \mathrm{mg} \mathrm{Zn/kg}$ per $\mathrm{d}_{5}$ fed every fifth day and separated by $4 \mathrm{~d}$ of feeding a $\mathrm{Zn}$-deficient diet, (f) $\mathrm{I}=6 \mathrm{Mx} / 6 ; 18,36,72$, or $144 \mathrm{mg} \mathrm{Zn} / \mathrm{kg}$ per $\mathrm{d}_{6}$ fed every sixth day and separated by $5 \mathrm{~d}$ of feeding a Zn-deficient diet, and $(\mathrm{g}) \mathrm{I}=8 \mathrm{Mx} / 8 ; 24,48,96$, or $192 \mathrm{mg} \mathrm{Zn/kg}$ per $\mathrm{d}_{8}$ fed every eighth day and separated by $7 \mathrm{~d}$ of feeding a $\mathrm{Zn}$-deficient diet. Each $\mathrm{Zn}$ dose-time equivalent modulo comprised seven analogous $\mathrm{Zn}$ dose-rate idiorrhythms and was run as an independent experiment. The expected $v$. analysed $\mathrm{Zn}$ contents of all twenty-eight experimental diets are shown in Table 2.

Separate groups of rats underwent the conventional dose-response treatment where graded amounts of dietary $\mathrm{Zn}$ were fed continuously (every day, $\mathrm{I}=\mathrm{Mx} / 1$ ) and over the same length of time as idiorrhythmically-fed animals. The groups of animals continuously fed with various doses of $\mathrm{Zn}$ were randomly distributed and often replicated across all four modulos to control the chance for fluctuation relative to the fact that modulo groups were investigated separately (See Appendix). Consequently, the data for continuously-fed animals across all four modulos are shown together in the corresponding tables and figures as if they were coming from a single experiment. The mean expected (analysed) $\mathrm{Zn}$ contents of these diets were $(\mathrm{mg} \mathrm{Zn} / \mathrm{kg}): 3(3 \cdot 1), 6(6.4), 12(11 \cdot 8), 24$ (19.5), 60 (58.0), 120 (104), 240 (208), 300 (277), and 400 (415). The National Research Council (1995) Zn requirement of $12 \mathrm{mg} \mathrm{Zn/kg}$ diet for growing rats is equal to that of the $\mathrm{Zn}$ dose-rate $\mathrm{I}=$ $12 / 1\left(12 \mathrm{mg} \mathrm{Zn} / \mathrm{kg}\right.$ per $\left.\mathrm{d}_{1}\right)$. Therefore, $\mathrm{I}_{\mathrm{M} 12}=12 / 1$ was considered the control idiorrhythm.

Table 2. Zinc concentration ( $\mathrm{mg} \mathrm{Zn} / \mathrm{kg}$ diet) of experimental diets fed idiorrhythmically

(Expected (Ex) $v$. analysed (An) values are means and standard deviations for three determinations)

\begin{tabular}{|c|c|c|c|c|c|c|c|c|c|c|c|c|}
\hline \multirow{4}{*}{$\begin{array}{c}\text { Idiorrhythm* } \\
\left(\mathrm{mg} \mathrm{Zn} / \mathrm{kg} \text { per } \mathrm{d}_{n t h}\right)\end{array}$} & \multicolumn{12}{|c|}{ Modulo* $\left(\mathrm{mg} \mathrm{Zn} / \mathrm{kg}\right.$ per $\left.\mathrm{d}_{1}\right)$} \\
\hline & \multicolumn{3}{|c|}{ M3 Zn deficient } & \multicolumn{3}{|c|}{ M6 Low Zn } & \multicolumn{3}{|c|}{ M12 Adequate $\mathrm{Zn}$} & \multicolumn{3}{|c|}{ M24 Ample Zn } \\
\hline & \multirow[t]{2}{*}{$\mathrm{Ex}$} & \multicolumn{2}{|c|}{ An } & \multirow[t]{2}{*}{ Ex } & \multicolumn{2}{|c|}{ An } & \multirow[t]{2}{*}{ Ex } & \multicolumn{2}{|c|}{ An } & \multirow[t]{2}{*}{ Ex } & \multicolumn{2}{|c|}{ An } \\
\hline & & Mean & SD & & Mean & $\mathrm{SD}$ & & Mean & SD & & Mean & SD \\
\hline 0 & 0 & 0.5 & 0.03 & 0 & 0.5 & 0.03 & 0 & 0.5 & 0.04 & 0 & 0.6 & 0.07 \\
\hline $\mathrm{M} / 1$ & 3 & 2.8 & 0.02 & 6 & 6.4 & 0.3 & 12 & $11 \cdot 2$ & $0 \cdot 1$ & 24 & 19.5 & 0.2 \\
\hline $2 \mathrm{M} / 2$ & 6 & $5 \cdot 8$ & $0 \cdot 2$ & 12 & 13.7 & 0.4 & 24 & 19.5 & 0.2 & 48 & $40 \cdot 7$ & 0.5 \\
\hline $3 \mathrm{M} / 3$ & 9 & $8 \cdot 6$ & 0.2 & 18 & $19 \cdot 0$ & 0.3 & 36 & 30.6 & 0.5 & 72 & 65.4 & 0.5 \\
\hline $4 M / 4$ & 12 & $10 \cdot 8$ & 0.1 & 24 & 24.5 & 0.3 & 48 & 40.7 & 0.5 & 96 & 83.4 & 0.3 \\
\hline $5 \mathrm{M} / 5$ & 15 & 13.7 & 0.2 & 30 & 29.6 & $2 \cdot 1$ & 60 & 52.8 & 0.6 & 120 & 104.4 & 7.8 \\
\hline $6 \mathrm{M} / 6$ & 18 & 16.9 & 0.4 & 36 & 37.7 & 0.2 & 72 & 65.4 & 0.5 & 144 & 135.9 & 3.6 \\
\hline $8 \mathrm{M} / 8$ & 24 & 21.8 & 0.2 & 48 & 50.3 & 0.4 & 96 & 83.4 & 0.3 & 192 & $168 \cdot 1$ & 2.0 \\
\hline
\end{tabular}

* For details of terms and procedures, see Fig. 1 and pp. 174-178. 


\section{Experimental animals}

This study was approved by the Animal Use Committee of the U.S. Department of Agriculture, Agricultural Research Service, Grand Forks Human Nutrition Research Center and was in accordance with the guidelines of the National Research Council (1985) on the experimental use of laboratory animals.

Weanling, 21-d-old, male Sprague-Dawley rats (Sasco, Omaha, NE, USA) were kept in individual stainless steel cages with wire-mesh floors and located in a temperature$\left(22-24^{\circ}\right)$ and humidity- $(44-55 \%)$ controlled room on a $12: 12 \mathrm{~h}$ dark-light cycle. They were given free access to powdered experimental diets and deionized water (Super $\mathrm{Q}$ System, Millipore Corp., Bedford, MA, USA). After being fed on their respective diets for $24 \mathrm{~d}$, and deprived of food overnight $(16 \mathrm{~h})$, most of the rats were killed by halothane inhalation. Some of the rats were subjected to restraint stress by enclosing them individually in a plastic animal holder and allowing them to remain there for $30 \mathrm{~min}$. This restricted the animal's movement but did not completely immobilize it (Klevay \& Halas, 1991). These rats were then killed by decapitation and the expression of aortal HSP70mRNA was determined.

Immediately after the rats were killed, the aortas and small intestines were dissected out and the mucosal lining scraped from the intestine. Both aortas and mucosal scrapings were kept frozen at $-80^{\circ}$ until analysed for HSP70mRNA and iMT respectively. $\mathrm{Zn}$ content was determined in the dry ash of the left femur and left upper incisor (Momčilović et $a l .1975 a, b$ ) by ICAP-AES.

\section{Intestinal metallothionein by the cadmium-haemoglobin displacement assay}

Small-intestinal mucosa was analysed in idiorrhythmic M12, M24, and all groups of conventionally-fed rats. The mucosa was homogenized and prepared for iMT analysis by following the method of Eaton \& Toal (1982), except that a portion of the homogenate was heated for $5 \mathrm{~min}$ at $95^{\circ}$ and centrifuged for $5 \mathrm{~min}$ at $10000 \mathrm{~g}$. The Tris buffer also contained $1 \mathrm{mmol} 2$-mercaptoethanol/1, $\mathrm{pH} 7.4$. The amount of iMT in the mucosa was expressed as Cd-binding potential and calculated based on the assumption that $7.0 \mathrm{~g}$-atoms of $\mathrm{Cd}$ are bound per mole of iMT and that the molecular mass of Cd-iMT is about $6500 \mathrm{Da}$ (Reeves, 1995). Values were expressed as a percentage of the average value of iMT obtained from rats fed on the control idiorrhythm, $\mathrm{I}_{\mathrm{M} 12}=12 / 1$.

\section{Heat shock protein $70 \mathrm{mRNA}$ isolation and Northern hybridization analysis}

The restraint-stress-induced aortal HSP70mRNA was measured in selected groups of animals. The aorta was homogenized at high speed for $10 \mathrm{~s}$ (Tekmar, Cincinnati, OH, USA) in RNAzol (Tel-Test, Inc., Friendwood, TX, USA). Total cellular RNA was isolated by using the manufacturer's protocol (Tel-Test, Inc.) and was quantified spectrophotometrically before loading samples onto agarose gels. For Northern analyses, $10 \mu \mathrm{g}$ total RNA was denatured in formaldehyde and fractioned in $10 \mathrm{~g} / \mathrm{l}$ agarose gel containing 2.2 mol formaldehyde/l. RNA was transferred to Genescreen Plus membranes (DuPont, Boston, MA, USA) according to the manufacturer's recommended conditions in $1.5 \mathrm{~mol}$ $\mathrm{NaCl}$ and $0.15 \mathrm{~mol}$ of sodium citrate $/ \mathrm{l}$, then baked for $2 \mathrm{~h}$ at $80^{\circ}$; membranes were hybridized and washed at $65^{\circ}$ and the blot was probed with a HSP70 complementary DNA (cDNA). 


\section{Probes and labelling reactions}

A cDNA for HSP70, isolated from a Chinese hamster ovary cell line, was provided by Dr Albert J. Fornace, Jr (National Cancer Institute, Bethesda, MD, USA) (Fornace et al. 1989). This probe recognizes both constitutive and inducible members of the HSP70 gene family (Church \& Gilbert, 1984; Blake et al. 1990). Purified inserts were labelled with ${ }^{32} \mathrm{P}$ 2 '-deoxycytidine 5 -triphosphate (DuPont-NEN, Boston, MA, USA) by using the random primer method of Feinberg \& Vogelstein (1983).

\section{Densitometric analysis of Northern blots}

Before scanning the autoradiograms, a photographic negative of the ethidium bromide(Sigma, St. Louis, MO, USA) stained samples was used to eliminate degraded or unevenly loaded samples. Initially, if any sample appeared degraded, as evidenced by a less than $2: 1$ ratio of $18 \mathrm{~S}: 28 \mathrm{~S}$ ribosomal RNA(rRNA) or a noticeable smearing, it was removed from the analysis. The negative of the ethidium-stained sample was scanned densitometrically along with the resultant autoradiogram. If the density of the $18 \mathrm{~S}$ or $28 \mathrm{~S}$ rRNA bands of a given sample deviated by more than $10 \%$ from the mean density for all samples in a gel then it too was removed from the analysis. Densitometric values were then determined from digitized images of autoradiograms (Imaging Research Inc., St. Catharines, Ontario, Canada). Values were corrected for background and expressed as a percentage of the average signal in rats fed on the control $I_{M 12}=12 / 1$ (control idiorrhythm HSP70mRNA $=1 \cdot 00$ ). Gels were always prepared so that samples from all treatment groups were present on a single gel.

\section{Statistical analysis}

Results are expressed as means and standard deviations. All differences were considered significant if $P \leq 0.05$. The effect of four different dietary $\mathrm{Zn}$ dose-time equivalent modulos, each with seven analogous $\mathrm{Zn}$ dose-rate idiorrhythms, on aortal HSP70mRNA, and $\mathrm{Zn}$ content of the femur and the incisor were assessed by ANOVA. The Ryan-EinotGabriel-Welsh (REGW) multiple $F$ test (Einot \& Gabriel, 1975) was used to determine if the mean values between idiorrhythms of the same modulo were significantly different. The iMT results were analysed with a two-way ANOVA, differences between different modulos and analogous idiorrhythms were assessed by the REGW multiple $F$ test, and the differences between idiorrhythms were assessed with Tukey's studentized range test (Kleinbaum \& Kupper, 1978). The data for intestinal iMT and aortal HSP70mRNA were normalized against the control idiorrhythm before statistical analysis to control for the between-experiment variability.

The data for iMT induction in rats fed continuously with graded amounts of $\mathrm{Zn}$ in a conventional dose-response regimen $(\mathrm{I}=\mathrm{Mx} / \mathrm{l})$ were normalized to the mean value of iMT in the control idiorrhythm and fitted to a ln-ln regression model (Kleinbaum \& Kupper, 1978). The respective comparative data for total femur and incisor $\mathrm{Zn}$ for the same rats were fitted to a break-point assay model as described by Hunt \& Johnson (1992). The fitted models served as reference calibration standards for assessing the biological effects of idiorrhythmic $\mathrm{Zn}$ dose-rate feeding. 


\section{RESULTS}

Presentation of the data follows the dynamics of the natural physiological sequence: (a) entry of $\mathrm{Zn}$ into the gastrointestinal mucosa where iMT is induced, (b) circulatory distribution to the aorta where HSP70mRNA expression occurs, and (c) accumulation of $\mathrm{Zn}$ in the femur and incisor (amount and concentration). They are shown separately for the conventional dose-response and idiorrhythmic dose-rate feeding model respectively.

\section{Intestinal metallothionein}

For the conventional dose-response model the induction of iMT by continuous daily feeding of graded amounts of dietary $\mathrm{Zn}$ was fitted to a $\ln$-ln regression model (Fig. 2). The $\mathrm{In}(\mathrm{iMT})$ rose linearly with $\ln \left(\right.$ dietary $\mathrm{Zn}$ ) over the range from 3 to $415 \mathrm{mg} \mathrm{Zn} / \mathrm{kg}$ per $\mathrm{d}_{1}$.

For the idiorrhythmic dose-rate model the effect of $\mathrm{Zn}$ dose-rate idiorrhythm and $\mathrm{Zn}$ dose-time equivalent modulo on the relative concentration of iMT is shown in Table 3. Overall, the relative concentration of iMT was the same for rats fed on $\mathrm{Zn}$ dose-time equivalent M12 (adequate $\mathrm{Zn}$ ) or M24 (ample $\mathrm{Zn})(P=0.69)$. However, there was an overall effect of idiorrhythm on iMT, because rats fed by $I_{M 12}=24$ and $I_{M 24}=48 \mathrm{mg}$ $\mathrm{Zn} / \mathrm{kg}$ per $\mathrm{d}_{2}$ had significantly higher iMT than rats fed by the other idiorrhythms $(P<0.01)$. The analysis also showed that iMT induction in response to $\mathrm{Zn}$ within the

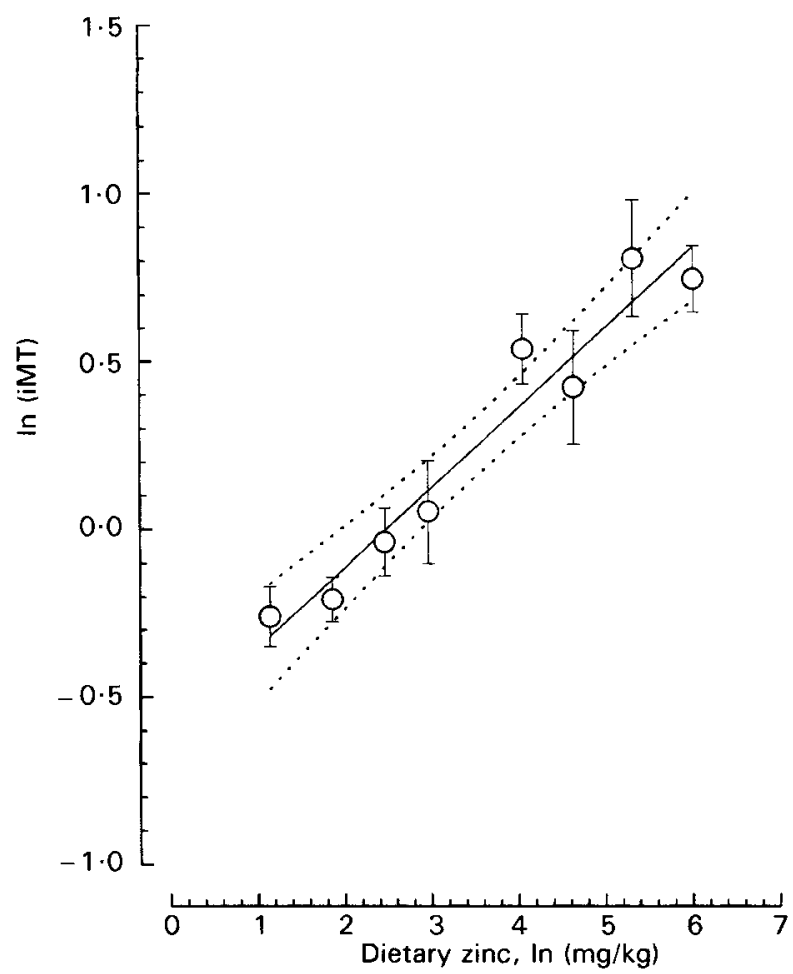

Fig. 2. Regression analysis of data relating $\ln$ intestinal metallothionein ( $\ln (\mathrm{iMT})$ ) concentrations with continuous daily feeding of graded amounts of dietary zinc over an entire idiorrhythmic epoch. Values are means with standard deviations represented by vertical bars for eight animals. (---), $95 \%$ confidence interval. Control idiorrhythm (iMT for $I=12 / 1)=1 \cdot 0$. For details of terms and procedures, see Fig. 1 and pp. 174-178. The equation for the curve is: $\ln (y)=-0.59+0.24 \ln (x), r^{2} 0.942$. 
Table 3. Effect of zinc dose-rate idiorrhythm (I) and zinc dose-time equivalent modulo $(M)$ on induction of intestinal metallothionein (iMT; expressed as a percentage of control iMT) after a 24 d idiorrhythmic epoch*

(Mean values and standard deviations for eight rats)

\begin{tabular}{|c|c|c|c|c|c|c|}
\hline \multirow{3}{*}{$\begin{array}{l}\text { Idiorrhythm* } \\
\left(\mathrm{mg} \mathrm{Zn} / \mathrm{kg} \text { per } \mathrm{d}_{n t h}\right)\end{array}$} & \multicolumn{6}{|c|}{ Modulo* (mg Zn/kg per $\mathrm{d}_{1}$ ) } \\
\hline & \multirow[t]{2}{*}{ I } & \multicolumn{2}{|c|}{$\mathrm{M} 12^{\mathrm{A}}$} & \multirow[t]{2}{*}{ I } & \multicolumn{2}{|c|}{$\mathrm{M} 24^{\mathrm{A}}$} \\
\hline & & Mean & SD & & Mean & SD \\
\hline $\mathrm{M} / 1^{\mathrm{B}}$ & $12 / 1 \dagger$ & $1.00^{\mathrm{bcd}}$ & 0.26 & $24 / 1$ & $1 \cdot 16^{b c d}$ & 0.47 \\
\hline $2 \mathrm{M} / 2^{\mathrm{A}}$ & $24 / 2$ & $1.87^{\mathrm{a}}$ & 0.51 & $48 / 2$ & $1.61^{\mathrm{a}}$ & 0.43 \\
\hline $3 \mathrm{M} / 3^{\mathrm{B}}$ & $36 / 3$ & $0.84^{\text {cd }}$ & 0.26 & $72 / 3$ & $1.03^{b c d}$ & 0.12 \\
\hline $4 \mathrm{M} / 4^{\mathrm{B}}$ & $48 / 4$ & $1 \cdot 17^{\mathrm{abc}}$ & 0.32 & $96 / 4$ & $1 \cdot 15^{\mathrm{bcd}}$ & 0.30 \\
\hline $5 \mathrm{M} / 5^{\mathrm{B}}$ & $60 / 5$ & $1.48^{\mathrm{ab}}$ & 0.41 & $120 / 5$ & $0.49^{\mathrm{d}}$ & 0.16 \\
\hline $6 \mathrm{M} / 6^{\mathrm{B}}$ & $72 / 6$ & $1.08^{b c d}$ & 0.30 & $144 / 6$ & $1.40^{\mathrm{ab}}$ & 0.80 \\
\hline $8 \mathrm{M} / 8^{\mathrm{B}}$ & $96 / 8$ & $0.85^{\text {bcd }}$ & 0.18 & $192 / 8$ & $1.24^{\mathrm{ab}}$ & 0.51 \\
\hline
\end{tabular}

A, B Two way ANOVA: M, $P<0.6878 ; \mathrm{I}, P<0.0001 ; \mathrm{M} \times \mathrm{I}$ interaction, $\mathrm{P}<0.0001$. M or I values bearing different upper case superscripts were significantly different $(P<0.05)$ by the REGW multiple $F$ test (Einot \& Gabriel, 1975).

a,b,c,d Mean values not sharing a common lower case superscript letter were significantly different, $P<0.05$ (Tukey's studentized range (HSD) test).

* For details of terms and procedures, see Fig. 1 and pp. 174-178.

$\dagger$ Control idiorrhythm.

modulo was bi-modal, with a secondary peak at $\mathrm{I}_{\mathrm{M} 12}=60 \mathrm{mg} \mathrm{Zn} / \mathrm{kg}$ per $\mathrm{d}_{5}$ and $I_{M 24}=144 \mathrm{mg} \mathrm{Zn} / \mathrm{kg}$ per $d_{6}$. The secondary peak shifted towards the higher idiorrhythms with an increase in the $\mathrm{Zn}$ dose-time equivalent modulo from M12 to M24. The lowest relative concentration of iMT was 0.84 when rats were fed by $I_{M 12}=36 \mathrm{mg} \mathrm{Zn} / \mathrm{kg}$ per $d_{3}$, and 0.49 when they were fed by $I_{M 24}=120 \mathrm{mg} \mathrm{Zn} / \mathrm{kg}$ per $d_{5}$.

The relative concentration of iMT in rats fed on the idiorrhythmic diets was always lower than that of rats continuously fed on diets containing $60 \mathrm{mg} \mathrm{Zn} / \mathrm{kg}$ per $\mathrm{d}_{1}$ or more. It was approximately equal to that in rats fed by $I_{M 12}=24 / 2$ and $I_{M 24}=48 / 2$, which apparently had the greatest iMT induction capacity.

\section{Restraint-stress-induced heat-shock protein $70 \mathrm{mRNA}$ expression in the aorta}

For conventional dose-response feeding an initial experiment (Momčilović et al. 1995) showed that values (expressed as a percentage of the control idiorrhythm) for aortal HSP70mRNA expression of restrained rats $(n 6)$ fed with $3,6,12$, and $300 \mathrm{mg} \mathrm{Zn/kg} \mathrm{per} \mathrm{d}_{1}$ daily were 0.52 (SD 0.27), 1.27 (SD 0.30), 1.00 (SD 0.55), and 1.03 (SD 0.55) respectively ( 3 v. $6 \mathrm{mg} \mathrm{Zn} / \mathrm{kg}$ per $\mathrm{d}_{1}, P<0.05$; Tukey contrasts). Aortal HSP70mRNA expression was lowest in rats fed continuously with the lowest concentration of dietary $\mathrm{Zn}(\mathrm{I}=3 \mathrm{mg} \mathrm{Zn} / \mathrm{kg}$ per $\mathrm{d}_{1}$ ). Increasing dietary $\mathrm{Zn}$ to $300 \mathrm{mg} \mathrm{Zn} / \mathrm{kg}$ per $\mathrm{d}_{1}$, well above that of the control idiorrhythm, did not affect the expression of aortal HSP70mRNA induced by restraint stress.

For the idiorrhythmic dose-rate model the effects of $\mathrm{Zn}$ dose-rate idiorrhythm and $\mathrm{Zn}$ dose-time equivalent modulo on aortal HSP70mRNA expression are shown in Table 4. It should be noted that the total number of samples analysed was small; however, none of the samples had to be excluded because of technical reasons. Rats that were fed continuously with $3 \mathrm{mg} \mathrm{Zn} / \mathrm{kg}$ per $d_{1}$ had decreased HSP70mRNA expression compared with rats fed by the control idiorrhythm $(P<0.05 ;$ Fig. 3). The aortal restraint-stress-induced 
Table 4. Effect of zinc dose-rate idiorrhythm and zinc dose-time equivalent modulo $(M)$ on the expression of restraint stress-induced aortal heat-shock protein $70 \mathrm{mRNA}$ (expressed as a percentage of control $\dagger)$ after a $24 d$ idiorrhythmic epoch*

(Mean values and standard deviations for four rats)

\begin{tabular}{|c|c|c|c|c|c|c|}
\hline \multirow{3}{*}{$\begin{array}{l}\text { Idiorrhythm* } \\
\left(\mathrm{mg} \mathrm{Zn} / \mathrm{kg} \text { per } \mathrm{d}_{n t h}\right)\end{array}$} & \multicolumn{6}{|c|}{ Modulo* $\left(\mathrm{mg} \mathrm{Zn/kg}\right.$ per $\left.\mathrm{d}_{1}\right)$} \\
\hline & \multicolumn{2}{|c|}{ M3 } & \multicolumn{2}{|c|}{ M12 } & \multicolumn{2}{|c|}{ M24 } \\
\hline & Mean & SD & Mean & SD & Mean & SD \\
\hline $\mathrm{M} / 1$ & $0.36^{\mathrm{c}}$ & 0.43 & $1.00^{\mathrm{a}}$ & 0.23 & - & \\
\hline $3 \mathrm{M} / 3$ & - & & $0.88^{a b c}$ & 0.33 & $0.84^{\mathrm{abc}}$ & 0.25 \\
\hline $5 \mathrm{M} / 5$ & - & & $0.51^{\mathrm{abc}}$ & 0.26 & $0.94^{\mathrm{ab}}$ & 0.21 \\
\hline $8 \mathrm{M} / 8$ & - & & $0.84^{\mathrm{abc}}$ & 0.20 & $0.37^{b c}$ & 0.36 \\
\hline
\end{tabular}

a,b,c Mean values not sharing a common superscript letter were significantly different $(P<0 \cdot 05)$ by the REGW multiple $F$ test (Einot \& Gabriel, 1975).

* For details of terms and procedures, see Fig. 1 and pp. 174-178.

$\dagger$ Control idiorrhythm $=12 / 1$.

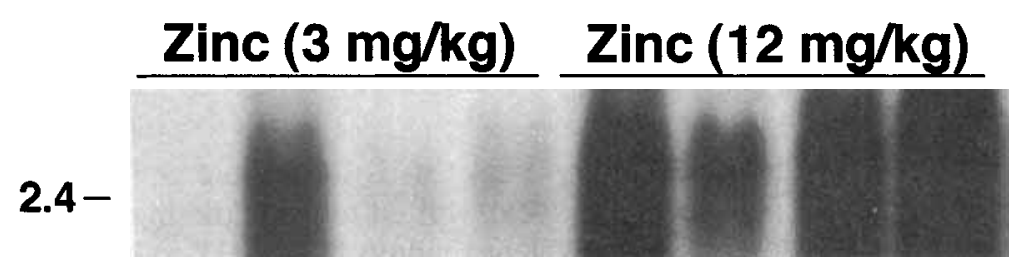

Fig. 3. Restraint-stress-induced heat-shock protein (HSP) $70 \mathrm{mRNA}$ in the aorta of rats fed with $3 \mathrm{mg} \mathrm{Zn} / \mathrm{kg}$ per $\mathrm{d}_{1}$ (idiorrhythm 3/1) or $12 \mathrm{mg} \mathrm{Zn} / \mathrm{kg}$ per $\mathrm{d}_{1}$ (idiorrhythm 12/1). Total RNA was isolated from the aorta of individual animals and assayed by Northern blot analysis. The HSP70 expression shown is for $10 \mu \mathrm{g}$ total RNA from the aortas of four rats for each dietary group. The blot was probed with a HSP70 complement DNA probe to recognize both constitutive and inducible members of the HSP70 gene family. Molecular mass marker $(2.4 \mathrm{~kb})$ is indicated on the left.

HSP70mRNA expression was lower for all of the tested idiorrhythms when compared with the control idiorrhythm. However, the differences were statistically significant only if rats were fed by the high degree $\mathrm{I}_{\mathrm{M} 24}=192 \mathrm{mg} \mathrm{Zn} / \mathrm{kg}$ per $\mathrm{d}_{8}(P<0.05)$.

\section{Femur and incisor}

For the conventional dose-response model the relationship between $\mathrm{Zn}$ deposition in the femur and incisor after conventional daily feeding of graded doses of dietary $\mathrm{Zn}$ is shown in Fig. 4. The break-point assay used here reasonably described the observed doseresponse pattern of $\mathrm{Zn}$ deposition in the femur and incisor over the entire range of dietary $\mathrm{Zn}$ concentrations tested $\left(3-415 \mathrm{mg} \mathrm{Zn} / \mathrm{kg}\right.$ per $\left.\mathrm{d}_{1}\right)$. The values for the break points that divided the initial rapid response phase of $\mathrm{Zn}$ deposition from the latter, almost flat, phase were $13.7 \mathrm{mg} \mathrm{Zn} / \mathrm{kg}$ per $\mathrm{d}_{1}$ and $14.4 \mathrm{mg} \mathrm{Zn} / \mathrm{kg}$ per $\mathrm{d}_{1}$ for the femur and incisor, respectively. It is of interest that these values closely match the dietary $\mathrm{Zn}$ requirement for the growing rat established by the U.S. National Research Council (1995). The difference in $\mathrm{Zn}$ requirements between the two calcified tissues did not exceed $5 \%$, a remarkably close correspondence for two sets of independent indicators.

For the idiorrhythmic dose-rate model the effects of $\mathrm{Zn}$ dose-rate idiorrhythm and $\mathrm{Zn}$ dose-time equivalent modulo level on femur and incisor $\mathrm{Zn}$ amount and concentration are 


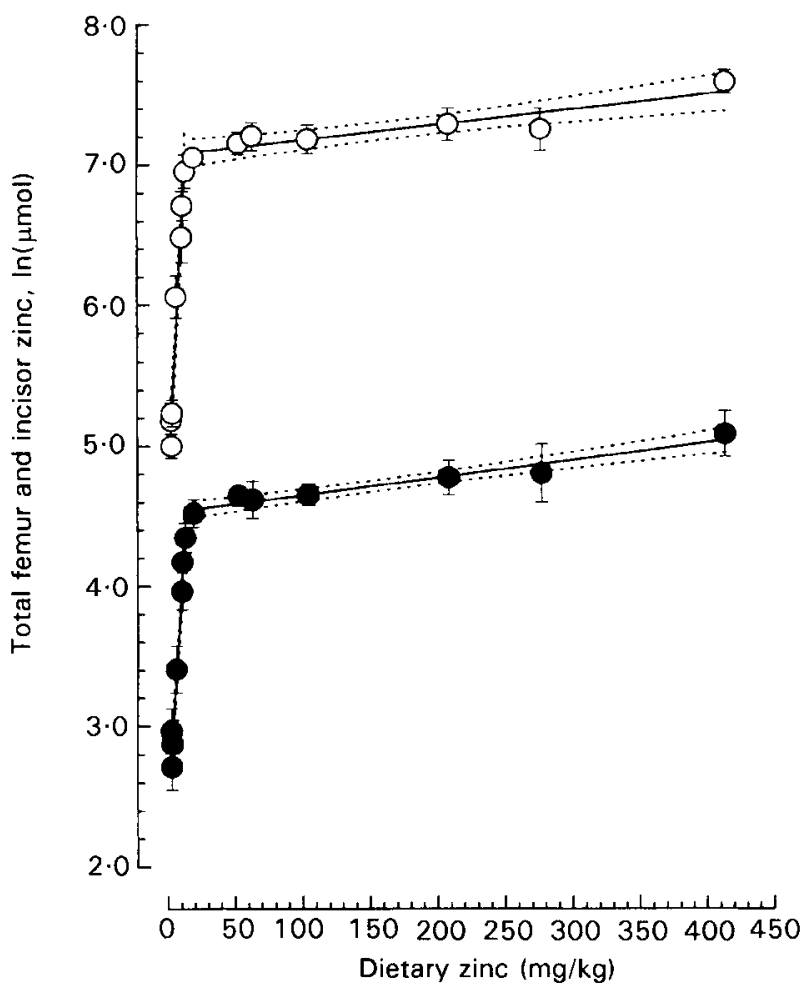

Fig. 4. Break-point analysis of the data relating femur $(O)$ and incisor $(O)$ zinc with continuous daily feeding of graded amounts of dietary zinc over an entire idiorrhythmic epoch. Values are means for eight animals with standard deviations represented by vertical bars; (---), $95 \%$ confidence interval. The equations for the two portions of the femur curve are $\ln (y)=4.63+0.18 x$ when dietary zinc is less than $13.7 \mathrm{mg} / \mathrm{kg}$, and $\ln (y)=7.07+0.001 x$ when dietary zinc is greater than $13.7 \mathrm{mg} / \mathrm{kg}$. For the two portions of the incisor curve, the equations are $\ln (y)=2.39+0 \cdot 15 x$ when dietary zinc is less than $14.4 \mathrm{mg} / \mathrm{kg}$, and $\ln (y)=4.53+0.001 x$ when dietary zinc is greater than $14.4 \mathrm{mg} / \mathrm{kg}$.

shown in Fig. 5 and Fig. 6 respectively. Among rats fed on the Zn-deficient M3 the amount and concentration of $\mathrm{Zn}$ in femur and incisor gradually increased with the progression of the idiorrhythms. Femur $\mathrm{Zn}$ content and femur and incisor $\mathrm{Zn}$ concentrations were lowest for $\mathrm{I}=3 \mathrm{mg} \mathrm{Zn} / \mathrm{kg}$ per $\mathrm{d}_{1}$, and highest for $\mathrm{I}=24 \mathrm{mg} \mathrm{Zn} / \mathrm{kg}$ per $\mathrm{d}_{8}(P<0.05$ for the femur and incisor pairs). When $\mathrm{Zn}$ dose-time equivalent was the $\mathrm{Zn}$-deficient M3 then the larger amplitude of $\mathrm{Zn}$ dose-rate resulted in a greater deposition of $\mathrm{Zn}$ in the femur and incisor, despite a low dose-rate frequency.

At the low Zn M6 the progression of the idiorrhythmic series resulted in a complex, bimodal pattern of $\mathrm{Zn}$ deposition in the femur. Femur $\mathrm{Zn}$ content and concentration decreased from $I=6 \mathrm{mg} \mathrm{Zn} / \mathrm{kg}$ per $d_{1}$, to $I=12 \mathrm{mg} \mathrm{Zn} / \mathrm{kg}$ per $\mathrm{d}_{2}$ and reached their nadir at $I=18 \mathrm{mg} \mathrm{Zn} / \mathrm{kg}$ per $\mathrm{d}_{3}$, and $\mathrm{I}=24 \mathrm{mg} \mathrm{Zn} / \mathrm{kg}$ per $\mathrm{d}_{4}$ respectively. Further progression of the idiorrhythmic series to $\mathrm{I}=30 \mathrm{mg} \mathrm{Zn} / \mathrm{kg}$ per $\mathrm{d}_{5}$ resulted in a significant $(P<0.05)$ rise in femur $\mathrm{Zn}$ content and concentration. This secondary increase peaked at $\mathrm{I}=30 \mathrm{mg} \mathrm{Zn} / \mathrm{kg}$ per $d_{5}$ and $I=36 \mathrm{mg} \mathrm{Zn} / \mathrm{kg}$ per $d_{6}$. The end result was that the animals fed daily by the continuous $I=6 / 1$ had the same $\mathrm{Zn}$ concentration in the femur as did the rats fed by $\mathrm{I}=30 / 5$ and $\mathrm{I}=36 / 6(P<0 \cdot 05)$. A similar but less pronounced pattern of $\mathrm{Zn}$ deposition occurred for $\mathrm{Zn}$ content and concentration in the incisor. 


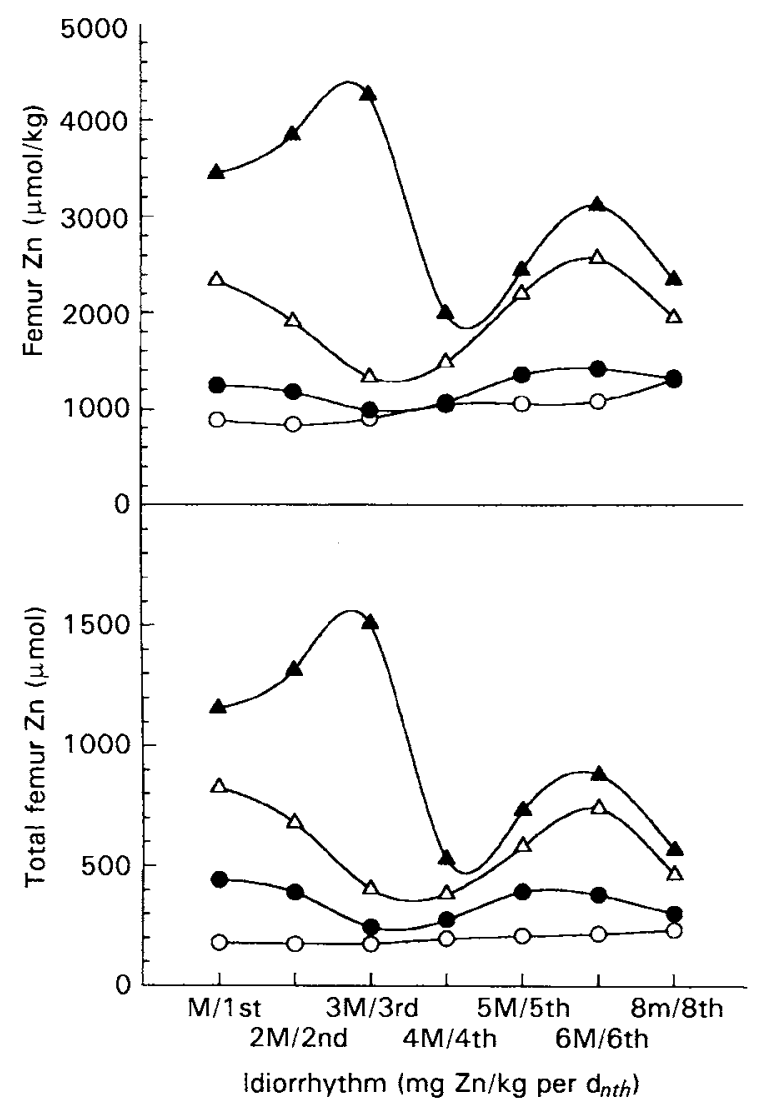

Fig. 5. The impact of zinc dose-rate idiorrhythm and zinc dose-time equivalent modulo (M) on zinc deposition in the femur of weanling male rats. Values are means for eight rats. $(O), \mathrm{M} 3 ;(0), \mathrm{M} 6 ;(\triangle), \mathrm{M} 12 ;(\Delta), \mathrm{M} 24$. The root mean square error (an estimate of overall standard deviation) is equal to 300 for femur zinc concentration and 80 for total femur zinc. For details of terms and procedures, see Fig. 1 and pp. 174-178.

The series of adequate Zn M12 idiorrhythms generated the same non-linear, bi-modal pattern of $\mathrm{Zn}$ deposition in the femur and incisor as that of the preceding low $\mathrm{Zn} \mathrm{M6}$ idiorrhythmic series, although of greater magnitude. Both femur and incisor $\mathrm{Zn}$ contents and concentrations decreased gradually from the initial, continuous daily $I=12 \mathrm{mg} \mathrm{Zn} / \mathrm{kg}$ diet per $d_{1}$, to reach the lowest level at $\mathrm{I}=48 \mathrm{mg} \mathrm{Zn} / \mathrm{kg}$ per $\mathrm{d}_{4}$. Thereafter, the values rose for $I=60 \mathrm{mg} \mathrm{Zn} / \mathrm{kg}$ per $d_{5}$, and reached their secondary peak at $I=72 \mathrm{mg} \mathrm{Zn} / \mathrm{kg}$ per $\mathrm{d}_{6}$. Femur and incisor $\mathrm{Zn}$ contents and concentrations at $\mathrm{I}=72 / 6$ reached the same level as in rats fed continuously by the control $I=12 / 1$. All M12 idiorrhythms had greater femur and incisor $\mathrm{Zn}$ contents and concentrations than the analogous M6 idiorrhythms.

When dose-time equivalent was increased two times above the daily $\mathrm{Zn}$ requirement (ample $\mathrm{Zn} \mathrm{M} 24$ ) it resulted in yet another response pattern of $\mathrm{Zn}$ accumulation in the femur and incisor. Their contents and concentrations first increased as the idiorrhythmic series progressed from $I=24 \mathrm{mg} \mathrm{Zn} / \mathrm{kg}$ per $\mathrm{d}_{2}$, to peak at $I=72 \mathrm{mg} \mathrm{Zn} / \mathrm{kg}$ per $\mathrm{d}_{3}$, then dropped about $50 \%$ when $\mathrm{I}=96 \mathrm{mg} \mathrm{Zn} / \mathrm{kg}$ per $\mathrm{d}_{4}$. However, when that drop was compared with the adequate $\mathrm{Zn}$ M12 idiorrhythms the values for $I_{M 24}=96 / 4$ were similar to that for $\mathrm{I}_{\mathbf{M} 12}=12 / 1$ idiorrhythm; the rats receiving the ample $\mathrm{Zn}$ M24 retained more $\mathrm{Zn}$ in the 


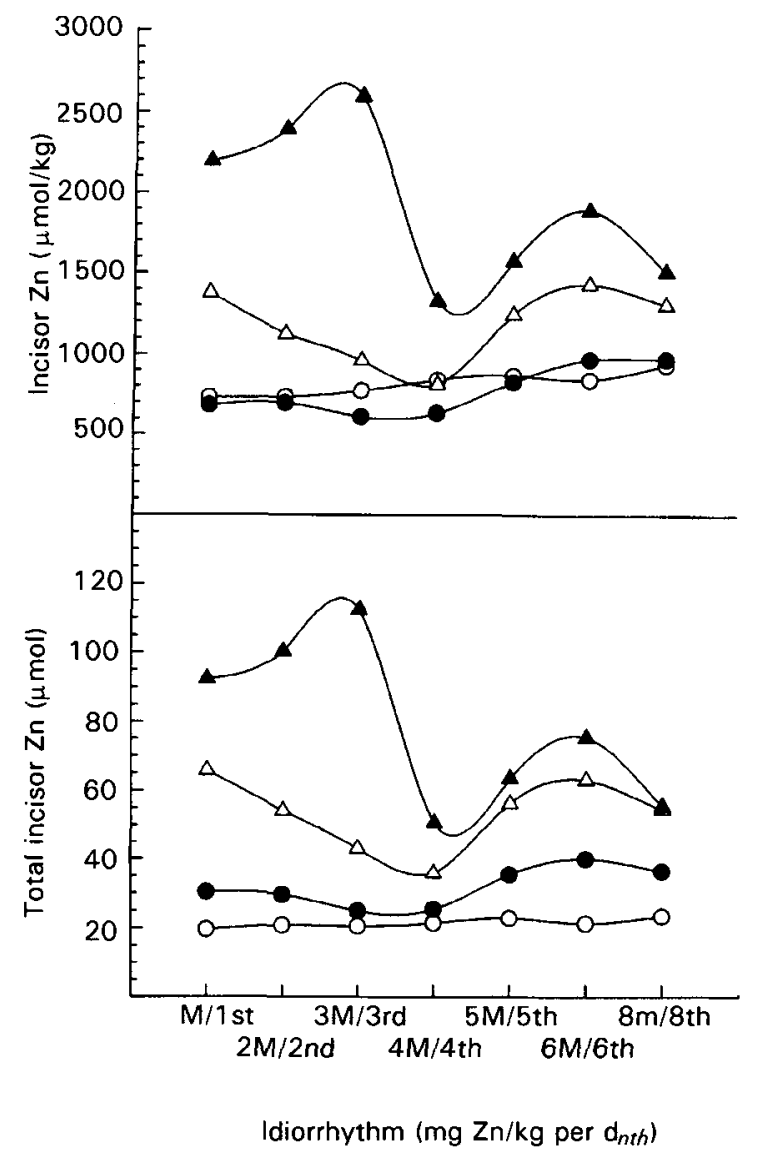

Fig. 6. The impact of zinc dose-rate idiorrhythm and zinc dose-time equivalent modulo (M) on zinc deposition in the incisor of weanling male rats. Values are means for eight rats. (O), M3; (O), M6; $\triangle(\triangle), M 12 ;(\Delta), M 24$. The root mean square error (an estimate of overall standard deviation) is equal to 182 for incisor zinc concentration and 8 for total incisor zinc. For details of terms and procedures, see Fig. 1 and pp. 174-178.

femur and incisor than rats receiving the $\mathrm{Zn}$-adequate $\mathrm{M} 12$. The secondary peak occurred when $\mathrm{Zn}$ was dosed every sixth day, $\mathrm{I}=144 \mathrm{mg} \mathrm{Zn} / \mathrm{kg}$ per $\mathrm{d}_{6}$, as was already observed with the analogous $I_{M 6}=36 / 6$ and $I_{M 12}=72 / 6$. The $I=144 / 6$ barely matched that of the continuous $I=24 / 1$ regarding $\mathrm{Zn}$ accumulation in the femur and incisor, and was significantly lower than that for $I=48 / 2$ and $I=72 / 3 \quad(P<0.05$ for the femur and incisor).

\section{DISCUSSION}

The results of the present experiment show that the idiorrhythmic dose-rate variability of dietary $\mathrm{Zn}$ intake generates different patterns of $\mathrm{Zn}$ accumulation in the femur and incisor, iMT induction, and in the expression of aortal HSP70mRNA than the conventional doseresponse feeding of a constant daily dose of dietary $\mathrm{Zn}$. Evidently, different dose-rates of dietary $\mathrm{Zn}$ modify the biological response of experimental animals in a hitherto 
unrecognized way indicating the important role that temporal variability in dietary $\mathrm{Zn}$ intake has on the functional metabolic response.

In contrast to the conventional daily feeding of graded amounts of dietary $\mathrm{Zn}$ in a classical dose-response model, the idiorrhythmic short time cycling of an excessive $\mathrm{Zn}$ load followed by a more protracted period of feeding the diet without $\mathrm{Zn}$ did not affect iMT and HSP70mRNA. Idiorrhythmic feeding resulted in an increase of iMT only when a double dose of $\mathrm{Zn}$ was fed every other day. Because iMT induction is greatest $18 \mathrm{~h}$ after gastric intubation (Menard et al. 1981), and because the half-life for iMT is considered to be less than $24 \mathrm{~h}$ (Richards \& Cousins, 1976), the increase in iMT of rats fed with a double dose of $\mathrm{Zn}$ every other day $(\mathrm{I}=2 \mathrm{M} / 2)$ may reflect the accumulation of newly induced iMT on the yet unmetabolized iMT from the preceding $\mathrm{Zn}$ dosing period. The other idiorrhythms did not appreciably change iMT values above those of the control idiorrhythm. This suggests that the dosing days were separated by $\mathrm{Zn}$-deficient periods long enough to preclude an accumulation of iMT, or any other tachyphylactic adaptation (Gershengorn, 1994). (Tachyphylaxis is a decreased biological response to a stimulus of constant strength, notably an excessive or pharmacological one.)

The final $\mathrm{Zn}$ dose in the conventional dose-response feeding of constant amounts of dietary $\mathrm{Zn}$ is considered to be the most important determinant of iMT concentration, but recent investigation showed that such induction of iMT with high doses of dietary $\mathrm{Zn}$ is not permanent. First it rises but thereafter it decreases to almost normal values over a prolonged period of feeding high $\mathrm{Zn}$. This suggests that iMT induction may be regarded only as a temporary safety mechanism that impedes excessive $\mathrm{Zn}$ accumulation (Reeves, 1995). Apparently, idiorrhythmic dose-rate cycling of the dietary Zn load does not pose a biochemical risk to the organism that needs to be counterbalanced by an increase in iMT induction. The observation that iMT induction was not $\mathrm{Zn}$ dose-dependent under the conditions of idiorrhythmic feeding opens a possibility for bypassing the so called 'mucosal block' by adequate spacing of nutrient intake.

The present experiment with young growing rats confirmed the previous finding with young adult rats (Momčilović et al. 1993) that the expression of aortal HSP70mRNA induced by restraint stress is markedly decreased if rats are fed continuously on a $\mathrm{Zn}$ deficient diet $\left(\mathrm{I}_{\mathrm{M} 3}=3 / 1\right)$. Similarly idiorrhythmic feeding did not increase aortal HSP70mRNA expression in restrained rats. In fact, aortal HSP70mRNA expression for the ample $\mathrm{Zn}$ intake $\mathrm{I}_{\mathrm{M} 24}=192 / 8$ was significantly less than in the control group. Such a high idiorrhythmic bolus of dietary $\mathrm{Zn}$ is still below the dose that may adversely affect humans (Fosmire, 1990), and apparently does not act as a stress factor that would stimulate aortal HSP70mRNA expression.

Our results with the break-point assay of $\mathrm{Zn}$ bioavailability are in good agreement with those of Hunt \& Jackson (1992). We inferred that the results of idiorrhythmic feeding could not have been influenced by the timing of each study because the data from a break-point assay on femur and incisor of continuously-fed animals came from random and replicated treatments across all four modules. Femur and incisor data showed a remarkably close correspondence with not more than $5 \%$ difference between the two independent indicators. The existence of the break point is a clear demonstration that the deposition of $\mathrm{Zn}$ in the femur and incisor is controlled by an ultra-sensitive threshold switching mechanism. Ultrasensitive is defined as a response in a biological system that is more sensitive than is to be expected from the classical hyperbola of Michaelis-Menton kinetics (Koshland, 1987). Small changes in the doses of dietary $\mathrm{Zn}$ below that indicated by the break point cause a very large change in output. The results fully correspond with the slope-ratio assay for the 
assessment of $\mathrm{Zn}$ bioavailability from food as proposed by Momčilović et al. (1975a, 1976). Because of the operation of an ultra-sensitive threshold switch, an increase in dietary $\mathrm{Zn}$ above that indicated by the break point results in only a gradual deposition of $\mathrm{Zn}$ in the femur and incisor.

While the increase in the dose-time equivalent from adequate $\mathrm{Zn}$ M12 to ample $\mathrm{Zn}$ M24 resulted in a marked increase in $\mathrm{Zn}$ content and concentration of femurs and incisors for each of the analogous idiorrhythms, the iMT values, for the most part, remained unchanged. This indicates that significant amounts of dietary $\mathrm{Zn}$ were indeed absorbed without appreciable iMT induction. The magnitude of idiorrhythmically induced temporal increases in the deposition of $\mathrm{Zn}$ in femurs and incisors may be, in fact, much greater than the overall results show.

Deposition of minerals into bone is characterized by at least two phases, initial deposition in the so-called exchangeable or partially reversible fraction of the bone, and irreversible deposition in the bone crystal lattice (Marshall et al. 1973). The process occurs as a laminar deposition in the newly formed or intensively remodelled regions of the bone (Turner et al. 1993; Martin, 1994). The process is somewhat different in teeth; the rat incisors are growing by a undirectional and irreversible accretion of minerals (Bronner, 1964). As the number of days between dosing of $\mathrm{Zn}$ increased, the layers of $\mathrm{Zn}$ deposited in the bone would be separated by large layers of newly formed bone without $\mathrm{Zn}$. However, a mere $\mathrm{Zn}$ analysis of the femur and incisor would not detect whether the calcified tissues were uniformly labelled or not; therefore, the high amount of bone $\mathrm{Zn}$ laid down idiorrhythmically would be obscured within the total bone mass.

The results on femur and incisor $\mathrm{Zn}$ accumulation showed that, although the offered dose was the same for all the idiorrhythmically-fed animals that belonged to the same modulo, $\mathrm{Zn}$ deposition differed, i.e. the $\mathrm{Zn}$ dose-rate idiorrhythm changed the metabolic efficiency of $\mathrm{Zn}$. We did not measure food intake, but be that as it may, any change in food intake, appetite, palatability, or metabolic utilization, either separately or in combination, results from a change in the $\mathrm{Zn}$ dose-rate idiorrhythm. In other words, a change in $\mathrm{Zn}$ deposition in the indicator tissues, femur and incisor, is the common vector of all changes that may occur in the different components of the whole animal.

The idiorrhythmic feeding regimen revealed that weanling rats have a different response pattern of $\mathrm{Zn}$ deposition in the femur and incisor depending on whether the total dietary $\mathrm{Zn}$ supply is deficient, low, adequate, or ample. It is tempting to conclude that if partitioning of a totally available amount of $\mathrm{Zn}$ in an otherwise $\mathrm{Zn}$-scarce nutritional environment can be controlled, it may be advantageous to indulge in $\mathrm{Zn}$ excess from time to time rather than to consume a moderately $\mathrm{Zn}$-deficient diet all the time. Indeed, such a behavioural phenomenon has been observed in all the known human cultures where long stretches of simple and often inadequate diets are regularly interrupted by seemingly irrational carnival feasts.

Our results clearly demonstrate that, in contrast to the classical dose-response model, the component of time should not be ignored in the analyses of biological systems. The idiorrhythmic dose-rate feeding offers the possibility of bridging the gap between the classical dose-response studies and time-related phenomena of chronobiology. A large number of infradian rhythms $(>24 \mathrm{~h})$ have been observed in weanling rats, one of which has a duration of $5.4 \mathrm{~d}$ (Mercer et al. 1993). This corresponds to the secondary peak of $\mathrm{Zn}$ deposition in the femur and incisor in the present experiment, and that of body growth as observed in a previous study (Momčilović, 1995). This may be interpreted as an interaction 
between the extrinsic idiorrhythm of nutrient intake and an underlying intrinsic infradian rhythm in the body. We think that the biochemical basis for such a biochemical inference may be related to metabolic channelling (Ovadi, 1991), futile metabolic cycles (Belfiore \& Iannello, 1990) and conditions when certain biological functions are controlled by two or more subsystems that may differ in their response time (Hurwitz et al. 1987).

Homeostasis and biological rhythms are both well-known natural phenomena but only rarely have investigators connected the two (Hyndman, 1974). Like any other physiological signal that elicits a response (Sato, 1971), nutrient intake acts as a time signal for circadian rhythms (Johnson, 1992), so that in ultima linea, the whole gastrointestinal tract can be viewed as a specific sensory organ that processes the nutritive signal. Most of the existing literature related to bioperiodicity aims (a) to prove that biological rhythms exist in and of themselves, and that they are not induced or entrained by light or food or some other signal, and (b) to separate circadian and learned rhythms on the basis of differences in pacemaker states. In contrast, idiorrhythmic feeding offers an active experimental approach that can unmask the underlying bioperiodicity of the organism, which is viewed as an integrated gestalt phase space (Momčilović, 1995). (Gestalt phase space is defined as a structure or configuration of physical, biological or psychological phenomena integrated to constitute a functional unit with properties non-derivable from its parts.) Indeed, we think that nutrition and metabolism should be viewed more as a metabolic network analogous to the neural network, if we are ever to come close to a clearer understanding of adaptability, addiction, tolerance, and/or the impact of change in metabolic fuels.

The possible implications of the idiorrhythmic merging of dose with time, and beyond the conventional dose-response model, may be far reaching. It was argued that with more information about nutrient-gene interactions and individual genetic identity, it may be possible to genotype populations so that food recommendations can be made on a more rational and individualistic basis; one that includes not only the dimensions of sex, age, and body size, but also the dimension of the genetic code so that we may choose foods that potentiate our genes for good health (Berdanier, 1993). The results of studies using idiorrhythmic dose-rate variability suggest that the dimension of time stimulation or nutrient signalling, and their metabolic networking within the biological gestalt phase space, should be considered essential for meaningful promotion of the nutritional genes. Otherwise, as D'Arcy Thompson said, 'Sooner or later, nature does everything that is physically possible. Our problem is, that which is physically possible may not be good enough' (cited by Waterlow, 1986).

The authors wish to thank Janet Hunt for the use of her laboratory for the study of idiorrhythms; Laura Idso, Brenda Skinner, Lana Stallard, Kathy LaVoi, and Jeannine Matz for technical assistance; James Lindlauf for preparation of the diets; Denice Schafer and her staff for care of rats; Terry Shuler for Zn analyses; LuAnn Johnson and Sheila Bichler for statistical analyses; Terry Kuntz for graphics; Sharon Peterson for manuscript management; David Milne, Jack Saari and Eric Uthus for critical reviews of the manuscript; and Forrest Nielsen, Director USDA, ARS, Grand Forks Human Nutrition Research Center, for his interest, support and encouragement during these studies. B.M. would also like to thank RCS Trading Co. Ltd., Isle of Man, UK, for the generous philanthropic support. 
APPENDIX

Experimental plan

\begin{tabular}{lcccc}
\hline \hline Modulo.. & M3 & M6 & M12* & M24* \\
Start date... & $17 / 7 / 92$ & $9 / 6 / 93$ & $23 / 9 / 93$ & $30 / 9 / 93$ \\
Finish date.. & $11-12 / 8 / 92$ & $\begin{array}{c}5-6 / 7 / 93 \\
\text { Idiorrhythm } \dagger\end{array}$ & $18-19 / 10 / 93$ & $25-26 / 10 / 93$ \\
Animal no. & & & \\
\hline $1-8$ & $3 / 1$ & $6 / 1$ & $12 / 1$ & $24 / 1 \S$ \\
$9-16$ & $6 / 2$ & $12 / 2 \ddagger$ & $24 / 2 \S$ & $48 / 2 \S$ \\
$17-24$ & $9 / 3$ & $18 / 3$ & $36 / 3$ & $72 / 3 \S$ \\
$25-32$ & $12 / 4 \ddagger$ & $24 / 4$ & $48 / 4 \S$ & $96 / 4 \S$ \\
$33-40$ & $12 / 1 \ddagger$ & $30 / 5$ & $60 / 1 \ddagger$ & $120 / 1 \|$ \\
$41-48$ & $15 / 5$ & $36 / 6$ & $60 / 5 \ddagger$ & $120 / 5 \|$ \\
$49-56$ & $18 / 6$ & $48 / 8$ & $72 / 6 \S$ & $144 / 6$ \\
$57-64$ & $24 / 8$ & $3 / 1$ & $96 / 8 \S$ & $192 / 8$ \\
$65-72$ & $300 / 1$ & $12 / 1 \ddagger$ & $120 / 1 \|$ & $240 / 1$ \\
$73-80$ & & $60 / 1$ & $3 / 1$ \\
$81-88$ & $400 / 1$ & & \\
\hline
\end{tabular}

* The start dates of M12 and M24 were only 1 week apart, i.e. they overlapped.

$\dagger$ Idiorrhythms of the format $x / 1$ represent continuous feeding.

$\ddagger$ Identical diet was fed either continuously or idiorrhythmically within the same modulo.

$\S$ Identical diets were fed idiorrhythmically between the different modulos.

|| Identical diet was fed both idiorrhythmically and continuously within and between the modulos.

\section{REFERENCES}

Belfiore, F. \& Iannello, S. (1990). A formula for quantifying the effects of substrate cycles (futile cycles) on metabolic regulation. Its application to glucose futile cycle in liver as studied by glucose- 6 phosphate/ glucokinase determinations. Acta Diabetologica Latino-Americana 27, 71-80.

Berdanier, C. D. (1993). The new age of nutrition. FASEB Journal 8, 4-5.

Blake, M. J., Gershon, D., Fargnoli, J. \& Holbrook, N. J. (1990). Discordant expression of heat shock protein mRNA in tissues of heat-stressed rats. Journal of Biological Chemistry 265, 15275-15279.

Bronner, F. (1964). Dynamics and function of calcium. In Mineral Metabolism, part 2A, pp. 341-417 [C. R. Comar \& F. Bronner, editors]. New York: Academic Press.

Church, G. M. \& Gilbert, W. (1984). Genomic sequencing. Proceedings of the National Academy of Sciences USA 81, 1991-1995.

Dunn, M. A., Blalock, T. L. \& Cousins, R. J. (1987). Metallothionein. Proceedings of the Society for Experimental Biology and Medicine 185, 107-119.

Eaton, D. L. \& Toal, B. F. (1982). Evaluation of the Cd/hemoglobin affinity assay for the rapid determination of metallothionein in biological tissues. Toxicology and Applied Pharmacology 66, 134-142.

Einot, I. \& Gabriel, K. R. (1975). A study of the powers of several methods of multiple comparisons. Journal of the American Statistical Association 70, 574-583.

Feinberg, A. P. \& Vogelstein, B. (1983). A technique for radiolabeling DNA restriction endonuclease fragments to high specific activity. Analytical Biochemistry 132, 6-13.

Fornace, A. J., Alamo, I., Hollander, M. C. \& Lamoreux, E. (1989). Induction of heat shock protein transcripts and B2 transcripts by various stresses in Chinese hamster cells. Experimental Cell Research 182, 61-74.

Fosmire, G. J. (1990). Zinc toxicity. American Journal of Clinical Nutrition 51, 225-227.

Gershengorn, M. C. (1994). Excessive stimulation is bad, so desensitization is ubiquitous. Endocrinology 134, $5-6$.

Gleerup, A., Rossander-Hulthen, L., Gramatkovski, E. \& Hallberg, L. (1995). Iron absorption from the whole diet: comparison of the effect of two different distributions of daily calcium intake. American Journal of Clinical Nutrition 61, 97-104.

Hunt, R. J. \& Johnson, L.-A. K. (1992). Dietary protein, as egg albumen: effects on bone composition, zinc bioavailability and zinc requirements of rats, assessed by a modified broken-line model. Journal of Nutrition 122, 161-169.

Hurwitz, S., Fishman, S. \& Talpaz, H. (1987). Calcium dynamics: a model system approach. Journal of Nutrition 117, 791-796.

Hyndman, B. W. (1974). The role of rhythms in homeostasis. Kybernetik 15, 227-236. 
Johnson, B. C. (1992). Nutrient intake as a time signal for circadian rhythm. Journal of Nutrition 122, 17531759.

Kelly, J. R. \& McGrath, J. E. (1988). On Time and Method, pp. 77-96. Newbury Park: SAGE.

Klevay, L. M. (1984). The role of copper, zinc, and other chemical elements in ischemic heart disease. In Metabolism of Trace Metals in Man, vol. 1, pp. 129-157 [O. M. Rennert and W. Y. Chan, editors]. Boca Raton, FL: CRC Press.

Klevay, L. M. \& Halas, E. S. (1991). The effect of dietary copper deficiency and psychological stress on blood pressure in rats. Physiology and Behavior 49, 309-314.

Kleinbaum, D. G. \& Kupper, L. L. (1978). Applied Regression Analysis and Other Multi Variable Methods. North Scituata, MA: Duxbury Press.

Koshland, D. E. (1987). Switches, thresholds and ultra sensitivity. Trends in the Biochemical Sciences 12, 225229.

Marshall, J. H., Lloyds, E. L., Rundo, J., Limiercki, J., Marotti, G., Mays, C. W., Sissons, H. A. \& Snyder, W. S. (1973). Alkaline earth metabolism in adult man. Health Physics 24, 125-221.

Martin, B. (1994). Mathematical model for the mineralization of bone. Journal of Orthopaedic Research 12, 375-383.

Menard, P., McCormick, C. C. \& Cousins, R. J. (1981). Regulation of intestinal metallothionein biosynthesis in rates by dietary zinc. Journal of Nutrition 111, 1353-1361.

Mercer, L. P., Haijazi, H. \& Hidvegi, M. (1993). Weanling rats display bioperiodicity of growth and food intake rates. Journal of Nutrition 123, 1356-1362.

Mertz, W. (1993). Essential trace metals: new definitions based on new paradigms. Nutrition Reviews 51, 267295.

Momčilović, B. (1988). The epistemology of trace element balance and interaction, Invited Lecture. In Trace Elements in Man and Animals, vol 6, pp. 173-177 [L. S. Hurley, C. L. Keen, B. Lönnerdal and R. B. Rucker, editors]. New York: Plenum Press.

Momčilović, B. (1995). Coupling of zinc dose to frequency in a regularly recurrent pattern shows a limited capacity of excessive dietary zinc to compensate for a previously deficient intake. Journal of Nutrition 125 , 2687-2699.

Momčilović, B., Belonje, B., Giroux, A. \& Shah, B. G. (1975a). Total femur zinc as a parameter of choice for a zinc bioassay. Nutrition Reports International 12, 197-203.

Momčilović, B., Belonje, B., Giroux, A. \& Shah, B. G. (1976). Bioavailability of zinc in milk and soy proteinbased infant formulas. Journal of Nutrition 106, 913-917.

Momčilović, B., Belonje, B. \& Shah, B. G. (1975b). Suitability of young rat tissue for a zinc bioassay. Nutrition Reports International 11, 445-452.

Momčilović, B., Blake, M. J. \& Buckley, A. R. (1993). Restrained stress-induced heat shock protein (HSP70) expression in aortas and adrenal glands of moderately zinc-deficient rats. In Trace Elements in Man and Animals, vol. 8, pp. 141-144 [M. Anke, D. Neissner and C. F. Mills, editors]. Gersdorf, Germany: Verlag Media Touristik.

Momčilović, B., Blake, M. J. \& Reeves, P. G. (1995). Aortal heat shock protein-70 mRNA (HSP70mRNA) and intestinal metallothionein (iMT) response in weanling rats fed graded levels of dietary zinc. FASEB Journal 9 , 4277 Abstr.

National Research Council (1985). Guide for the Care and Use of Laboratory Animals. Publication no. 85-23 (rev). Bethesda, MD: National Institute of Health.

National Research Council (1995). Nutrient Requirements of Laboratory Animals, 4th Revised Version. Washington DC: National Academy of Sciences.

Nielsen, F. H., Shuler, T. R., Zimmerman, T. J. \& Uthus, E. O. (1988). Magnesium and methionine deprivation affect the response of rats to boron deprivation. Biological Trace Element Research 17, 91-107.

Ovadi, J. (1991). Physiological significance of metabolic channeling. Journal of Theoretical Biology 152, 1-22.

Reeves, P. G. (1995). Adaptation responses in rats to long-term feeding of high-zinc diets: emphasis on intestinal metallothionein. Journal of Nutritional Biochemistry 6, 48-54.

Reeves, P. G. (1996). AIN-93 purified diets for the study of trace element metabolism in rodents. In Trace Elements in Laboratory Rodents pp. 3-37 [R. R. Watson, editor]. Boca Raton, FL: CRC Press.

Reeves, P. G., Nielsen, F. H. \& Fahey, G. C. Jr (1993). AIN-93: purified diets for laboratory rodents. Final Report of the American Institute of Nutrition ad hoc writing Committee on the reformulation of the AIN-76A rodent diet. Joumal of Nutrition 123, 1939-1951.

Richards, M. P. \& Cousins, R. J. (1976). Zinc binding protein: relationship to short term changes in zinc metabolism. Proceedings of the Society for Experimental Biology and Medicine 152, 52-56.

Sato, K. (1971). On the unified Laws of excitability, activity, and interactivity of physiological systems. Kybernetik 9, 45-55.

Smith, J. C. Jr (1994). Comparison of reference dose with recommended dietary allowances for zinc: methodologies and levels. In Risk Assessment of Essential Elements, pp. 127-143 [W. Mertz, C. O. Abernathy and S. S. Olin, editors]. Washington DC: ILSI Press. 
Turner, C. H., Boivin, G. \& Meunier, P. J. (1993). A mathematical model for fluoride uptake by the skeleton. Calcified Tissue International 52, 130-138.

Viteri, F. E., Xunian, L., Tolomei, K. \& Martin, A. (1995). True absorption and retention of supplemental iron is more efficient when iron is administered every three days rather than daily to iron-normal and iron-deficient rats. Journal of Nutrition 125, 82-91.

Waterlow, J. C. (1986). Metabolic adaptation to low intakes of energy and protein. Annual Reviews of Nutrition 6, 495-526.

Welch, W. J. (1992). Mammalian stress response: cell physiology, structure/function of stress proteins, and implications for medicine and disease. Physiological Reviews 72, 1063-1081. 